DOI: https://doi.org/10.31392/NPU-nc.series9.2018.18.01

UDC: $81 ’ 22+81$ ' $42: 811.11$

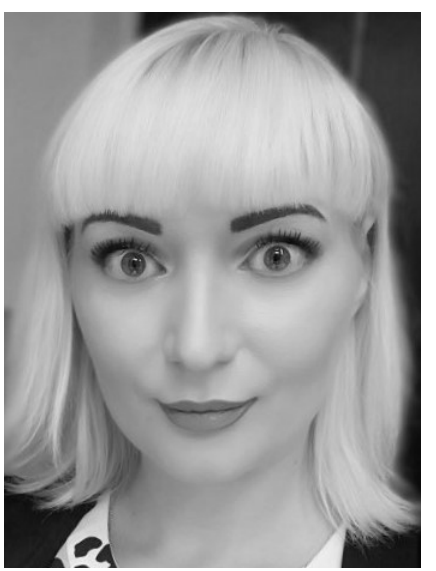

Kamianets-Podilskyi National Ivan Ohiienko University,

Kamianets-Podilskyi, Ukraine

\title{
REPRESENTATION MODEL OF HYPERREAL FANTASY WORLD: PHRASEOLOGICAL DIMENSION
}

\section{Bibliographic Description:}

Barbaniuk, O. O. (2018). Representation Model of Hyperreal Fantasy World: Phraseological Dimension. Scientific Journal of National Pedagogical Dragomanov University. Series 9. Current Trends in Language Development, 18. 5-22. DOI: https://doi.org/10.31392/NPU-nc.series9.2018.18.01

\begin{abstract}
The article focuses on the most traditional model of knowledge representation-frame, which is the key to discover the mechanisms for conceptualizing the phenomena of surrounding or text reality. Possible worlds, as text reality, are mental structures that need appropriate interpretation, in particular fictional worlds of the fantasy genre. Such worlds are posited as hyperreal, as they demonstrate the simulation of reality, replacing real by means of the signs of the objective reality - simulacra. The hyperreal world in the fantasy novels of the Earthsea cycle by an outstanding American novelist Ursula Le Guin is objectivized at lexical and phraseological levels, thus, by lexical units-simulacra and phraseological units-simulacra. Such expressive units are to be classified according to their semantics, denoting a person, a place, time and a separate notion. The prevailing number of magic component testified the founding and leading role of this phenomenon for the hyperreal world under investigation. It has been ascertained that phraseological units-simulacra, explicating the slots of the Thing, Action and Comparison Frames, enable to decode the information about the hyperreal world in general, enriching it with attributive and activity characteristics of characters in opposition - a person and a dragon. The proposed representation model of hyperreal fictional world ascertained the results and allowed to reveal the plane of the contents of the author's construct. Thus, phraseological units-simulacra are decoded in the slots of: 1) the Thing Frame (SB/STH is SUCH, SB/STH is (exists) SO, SB/STH is THERE), disclosing information about features and locations of characters; 2) the Action Frame (SB/STH acts UPON, $S B / S T H$ acts FOR, SB/STH acts BY MEANS OF), exposing their activity peculiarities; 3) the Comparison Frame (SB/STH is AS (LIKE)), enriching the hyperreal world under investigation with expressive-emotional characteristics.
\end{abstract}

Keywords: frame, slot, explication, representation model, hyperreality, simulacrum, phraseological unit-simulacra, fictional world, fantasy. 


\section{Introduction.}

Cognitive Linguistics has recently firmly rooted in the paradigm of contemporary world science hence, any thorough study of language is impossible without a cognitive approach (Croft, Cruse, 2004). Such an approach to language study stems from the necessity for knowledge understanding (expressed in the form of a text or speech). Thus, non-linguistic factors, which impede or facilitate the process of understanding, are to be taken into account and interpreted. As a result, Cognitive Linguistics broadens its ties with those sciences and disciplines whose subject matter is the factors that affect the functioning of language phenomena at any rate.

Consequently, the sphere of vital interests of Cognitive Linguistics includes the "mental" foundations of understanding and speech production from the perspective of how the structures of language knowledge represented and participate in the processing of information. Such representations and corresponding procedures subordinate to different principles of organization.

Whereas the cognitive paradigm in linguistic field is a relatively new trend, it symbolizes a fundamentally new approach to the process of conceptualising reality, mechanisms for shaping the conceptual picture of the world and individual concepts, and their objectification in language. Within the framework of the cognitive paradigm, special attention has been paid to the study of semantics, and in particular to its varieties, which are being currently developed - conceptual, prototypical, and framing.

Top-priority issues in Cognitive Linguistics are brought to the forefront of research (Pavlova, 2014: 118-124): language consciousness structure, knowledge forms representation, cognitive semantics, cognitive categories, cognitive strategies, cognitive models (Arutjunova, 2004; Boldyrev, 2004; Croft, 2004; Vezhbickaja, 1996; Zhabotinskaja, 2009; Kubrjakova, 2004; Lakoff, 1980; Selivanova, 2008; Telija, 1996; Tyshchenko, 2018)

According to linguistic tradition, the main model of knowledge representation in cognitive science is the "frame" (Zhabotinskaja, 1999: 12-25; Novosadska, 2018: 38). The first scholar to introduce this term into conceptual apparatus was the investigator of artificial intelligence and cognitive psychology Minskij (in sociology, the frame was used in concept of Hoffman, where the understanding of the term was borrowed from Mr. Bateson).

There is abundance in definitions of the term "frame" by outstanding linguists (Minskij, 1975; Fillmore, 1985; Zhabotinskaja, 1999; Tannen, 1979; Petruck, 1996; Nikonova, 2009; Koljadenko, 2018; Kozak, 2007; Novosadska, 2018), as well as concepts related to the theory of frames.

In his numerous works Fillmore (1985), the founder of the theory of frames, repeatedly referred to the need of taking frames into account (in the sense of Minskij (1975)), who defined the frame as a structure of information data, which reflects acquired knowledge of some stereotypical situation and about the text that describes it) in theories of lexical semantics and text understanding.

According to the theory of the scientist, frame - is a system of correlating concepts, and in order to the understand any of them one must comprehend the whole structure, to which this concept belongs (Petruck, 1996).

Following the ideas of Ch. Fillmore in his most recent works "frame" can be interpreted as:

1) a unit of knowledge, organized around the concept, which contains data on the substantial, typical and possible for this concept within particular culture (Boldyrev, 2000);

2) data structure for stereotypical situations presentation (Minsky, 1975: 211-215); 
3) a type of cognitive model representing the knowledge and associated thoughts within specific situations, the structure of knowledge that combines numerous spheres assimilated with a certain linguistic form (Boldyrev, 2000);

4) cognitive structure that exists in the individual phenomenological field, based on presumed knowledge about typical situations, expectations concerning the qualities and relations between real and hypothetical objects (Levickij, 1998: 168).

The study of frames (Baker, Ellsworth, Petruck) provides the key to discovering the mechanisms for conceptualizing verbalized notions and phenomena of environmental reality, hence frame analysis is becoming very popular not only among linguists, but also among literary critics and representatives of other branches of knowledge (Barbanjuk, 2012: 11-12).

Modern cognitive semantics is characterized by a tendency to studying possible worlds (Doléžel, Pavel, Ryan, Semino) as mental structures which reflect surrounding reality on the whole and text world in particular, which is a set of several sub-worlds (Semino, 1999).

At the same time, particular attention of scholars is still being paid to disclosure of ontological and epistemological nature of possible worlds in different literature genres, among which "fantasy" still remains a mysterious phenomenon (Attebery, 1980; Manlove, 1986; Kovtun, 1999; Plotnikova, 1998), which requires a deep comprehension through the prism of history, ethnography, anthropology, culturology, mythology, psychology, etc.

New perspectives are being opened for linguists to the study of fiction fantasy texts in perspective of possible worlds theory, borrowed into linguistics from the concepts of modal logics (Babushkin, Baranov, Ivanov, Lewis), where "possible worlds" are interpreted as:

a) mental constructions that "do not reflect the real picture" (Babushkin, 2001);

b) subjective worlds, created by means of objective realia (Vardzelashvili, 2003);

c) replacement of real worlds with signs of reality (Baudrillard, 1994) - simulation (illusion) of actual reality, disguising its absence.

Fictional world as well as the real one, according to Vardelashvili, can be studied in two perspectives (Vardzelashvili, 2003: 37-45): as a possible state and possible course of events (Babushkin, 2001: 5-8). In this respect, the correct interpretation of the concept "possible world" is required (Mamchur 2000), since it can be understood both ontologically (as distinct from the real world) and epistemologically (as another version of the real world). To our great concern, understanding possible worlds as different from the real one and existing only in the mental sphere is the most appropriate. There are plenty of definitions of such worlds in the scientific literature: irreal and quasireal (Medvedeva, 1991), virtual (Asmus, 2005; Lugovaja, 2007, 2010; Rudnev, 2000), anomalous fictional (Korotkova, 2000; Misnik, 2005; Plotnikova, 1998: 123-131), utopian worlds (Rozinkina, 2005), etc.

Such worlds are constructed be means of signs with no reference to the objective reality, which simulate reality, hence we use the term "hyperreal" to denote specific, distinct from the real, mental worlds. They are materialized in verbal signs with double referential assignment - an external (a transformational model that has no analogues in the real world) and an internal (objective reflection of the real world in fictional denotations). Such signs are posited as "simulacra".

Fantasy represents such worlds, which demonstratively do not coincide with the ordinary idea of reality. Normally, authors put action into a world invented by them with their own geography, their history, their races and peoples. Another prerequisite for fantasy is magic. Fantasy takes the existence of magic for granted. Moreover, it is the transpersonal, divine, mystical, founding and driving force. The best prove to these ideas, to our deep concern, are the fictional worlds of an outstanding American novelist Ursula Le Guin in her Earthsea cycle (B. 1 - B. 6). Her thoroughly-constructed words are hyperreal and materialized in signs of lexical and phraseological levels. 


\section{Aim and Objectives. Methodology.}

The aim of the paper is to present a model of hyperreal fantasy world at phraseological level, based on the texts of the Earthsea cycle by Le Guin.

Objectives of the paper:

- to substantiate the use of the term "hyperreal" to denote the fictional fantasy world;

- to find out the frame structure of this hyperreal world;

- to model hyperreal world of Ursula Le Guin's Earthsea at phraseological level.

The method of frame modelling is applied to interpret the content of the phraseological units-simulacra in the hyperreality of the Earthsea.

\section{Results.}

First appeared in postmodern philosophy, the term "hyperreality" refers to inability of consciousness to distinguish between reality and imagination, the simulation of what in fact never existed (Baudrillard, 1994), authentic fake (Eco, 1983), technological ability to merge virtual reality with physical reality. Hyperreality is more likely to characterize the method that guides consciousness in determining the "reality".

Hyperreality is posited as an infinite reproduction, a micro-segmentation of objects, transformation into model series, where real objects are absorbed by simulacra. Hence, "simulacra" (Baudrillard, 1994) are symbols without reference to the real world, which create over-real world, challenge the objectivity, truth and reality, only imitating their existence.

The perception and comprehension of the simulacrum is based on the external similarity effect with subject world, with large inadequacy with the inner essence of reality. The simulacrum creates the effect of the "wrong reality", hyperreality, and, by functioning in the text, it creates a special type of hero, world, as well as, outlook.

Such a special world with its rules and laws is a distinctive characteristic feature of the fantasy genre. Having appeared in the first half of the $\mathrm{XX}^{\text {th }}$ century in English prose, fantasy stays in between "science fiction" and a "fairy tale", but they should not be confused. Hence, science fiction is focused on the individual obsession with science, on the image of inventors, on forbidden knowledge; therefore, science in the works of science fiction is understood as driving force.

Unlike science fiction, fantasy does not seek to explain the world from scientific point of view. This world itself exists hypothetically, often its location in accordance to our reality is not specified: whether it is a parallel world, or another planet, and its physical laws may differ from earthly ones. In such a world, the existence of gods, witchcraft, mythical creatures (dragons, elves, gnomes, trolls), ghosts, and any other fantastic entities can be quite real. At the same time, the fundamental difference between fantasy and fairy-tale is that magic and wonders are normal for this world and act systemically, like the laws of nature in objective reality.

Fantasy novels most often resemble a historical adventure, thus action takes place in a fictional world close to the real Middle Ages, whose heroes are confronted with supernatural phenomena and mythical creatures. Hence, this literary genre is rich in poetic whimsical images, represents supernatural and unrealistic events and characters.

So, we can give the following definition of "fantasy" - it is a literary work, in which action takes place in a separate world with the indispensable presence of magic, or other phenomena that cannot be rationally interpreted. However, the author of fantasy is not limited either by the plot or thematically.

Among authors who have worked in fantasy genre, alongside with its founders Howard and Tolkien, we find the names of Lewis, Martin, Rowling, Howard, Le Guin. The heritage of Ursula Kroeber Le Guin is in the focus of our scientific interest. 
Being an outstanding American novelist, who worked mainly in the genres of fantasy and science fiction, Le Guin is still regarded as one of the most successful and popular authors in epic fantasy.

The creative work of Le Guin (1929-2018) has been in focus of scientific interest in different spheres:

a) psychology and philosophy (Bailey, Barrow, Littlefield, Mahy, Reid, Walker),

b) literature (Bittner, Clayton, Cummings, Griffin, Heng);

c) linguistics (Algeo, Philippopoulos-Mihalopoulos, Robinson, Shippey, Tsai).

Her unique utopian hyperreal worlds, as well as unlimited linguistic potential of the works, still attract many scientists.

The fantasy novels of Ursula Le Guin are original, the hyperreal worlds of the author are verified and perfect (Philippopoulos-Mihalopoulos, 2005), difficult to relate to any spatio-temporal reality. Thus, in the history and philosophy of the Earthsea Archipelago (Le Guin's own fictional detailed world) one can find a combination, a mixture of fantastic elements and elements belonging to various ancient philosophies and mythologies: Scandinavian, Celtic, Chinese.

However, some researchers tend to consider (Lomakova, 2005) that fantasy fiction of Le Guin is somewhat different from the traditional understanding of the genre, since her heroes do not try to fight the world of Evil and compete with evil monsters: the purpose of their lives is to maintain world Equilibrium. Thus, both Good and Evil have equal rights to exist in the world, created by Le Guin. Moreover, a number of Le Guin writings, including the Earthsea series, challenged the conventions of epic fantasies and myths (Bernado, Murphy). For instance, many of the protagonists in Earthsea are dark-skinned individuals, some of the antagonists, in contrast, were white-skinned, which contradicts fantasy tradition (Bernado, 2006).

To our deep concern, the key point in referring works of Le Guin to fantasy genre is the magic component as the founding element in the lives of her heroes. The best verification to this idea is Le Guin's "Earthsea cycle", which is composed of the following novels: "A Wizard of Earthsea" (B.1 WE), "The Tombs of Atuan" (B.2 TA), "The Farthest Shore" (B.3 FS), "Tehanu. The Last Book of Earthsea" (B.4 LBE), "The Other Wind" (B.5 OW), "Tales from Earthsea" (B.6 TE). These first four cycle novels are known under the name "Earthsea quartet", an example of a heroic fantasy - a story about the protagonist, named Ged, who learns the world, is looking for his self. By trying to restore the world balance of the Dark and Light he loses his most valuable abilities - his magic.

Hyperreal world, created by the author, is built on magic, which is based on the knowledge of the True Names of all living beings and inanimate creatures, which allows not only to comprehend the essence of everything, but also to manage the whole world. Thus, the mastery of the sacred True language (the Old Speech), the Creation language is the key to power, to the self, and at the same time the basis of the simulated hyperreality.

The image of Le Guin hyperreal world is closely interconnected with the well-known Tao symbols - Yin and Yang (Bain, 1986), the essence of which is to combine the opposites. Hence, Earthsea is the world of opposing, but interrelated concepts: water / land, white magic / black magic, ordinary people / people with magic skills, women / men, fair-skinned / dark-skinned, light / darkness, ordinary people / royals and other.

Thus, the fictional author's world in the novels of Le Guin of the Earthsea cycle, is a specific mental construction of reality which is complemented by new features, gets a shade of subjectivity, where the miracle is allowed and everything is possible. 
Characters in the Earthsea cycle are endowed with magical skills, abilities that significantly differentiate them from ordinary people and open up new real possibilities. It is posited that they are over-real, hyper-real. The effect of hyperreal is achieved in the texts by a number of signs with no reference to anything from objective reality, which are the basis of the simulation of reality.

We claim that any fictional world of the fantasy genre is to be defined as "hyperreal" in its understanding that this is a simulation of reality. This is a specific world with its own laws, comprehended as a secondary world, organised on other principles than the ordinary world, but its perception is possible only based of the real world (Il'inova, 2007: 85-93). The interrelation between the simulated and real worlds (Baksanskij, 2001), the elements of fiction and reality form hyperreality.

The world of Le Guin's Earthsea cycle is a world created by simulacra.

For instance, the word combination Old Speech is an absolute reflection of the basic reality, with a clearly defined form and content - the tongue in which things are named (B.1. WE).

Nevertheless, such reality is later distorted, modified by the following explanation - the language of spells, lays, songs, invocations, enchantments (B.1. WE). And when, in fact, we encounter another interpretation of Old Speech - the language of dragons and wizards (B.1. $\mathrm{WE})$, the language the dragons speak; no one can learn it (B.1. WE), then the reality disguise becomes quite apparent. Therefore, when the author focuses on the fact that there is no end to this language, this is why no one can learn it to the end (B.1.WE), then reality in its usual sense (the true form of the existence, the opposite of the notion of "illusion", "science fiction") is lost. To sum it up, another example proves the absence of reality - this is the Hardic Tongue of the Earthsea (B.1. WE). The illustrations from the text give all reason to recognize such sign (Old Speech) as simulacrum, a sign without reference.

Another example of the sign where form does not correspond to its usual content is lexeme Shadow, though it possesses some "real" characteristics - Dark substance (B.1. WE). However, that creature was bodiless, blind to sunlight, a creature of a lightless, timeless realm (B.1. WE), i.e. SHADOW IS CREATURE. Masking the lack of reality, the author gives the following characteristic - it was not a ghost of a human man, nor was it a creature of the Old Powers (B.1. WE).

In the end, Shadow gets its real quality - able to take everyone's form and shape (B.1. WE), an evil creature, the shadow-beast (B.1. WE). Consequently, the beforementioned references give reason to assume that the sign Shadow (in the author's interpretation) is a simulacrum, since its correlation with reality is neglected.

Thus, the simulacra that create the hyperreal world of the Earthsea cycle are lexical and phraseological units, with no reference to objective reality, hence they are "lexical unitssimulacra" and "phraseological units-simulacra".

To understand the essence of the hyperreal world, to comprehend it, it is necessary to reveal the meaning of these non-referential units.

At phraseological level, hyperreality of the Ursula Le Guin Earthsea cycle is created by figurative, situational units - phraseological units-simulacra, which add to the author's hyperreal world expressiveness, evidence its peculiar relation to the objective world.

The effect of hyperreality is being achieved by means of phraseological units (170 in number), which, following Chepasova, according to their semantics, are divided into three subcategories and designate:

1) a person - with somatic (28 units), gender (23 units) and animal (26 units) components; 
2) place and time - with local (18 units) and temporal (4 units) components;

3) a separate notion - with magic (50 units) and anthropomorphic (21 units) components.

The most numerous in course of analysis was a subcategory to identify a person, including the group of phraseological units with a somatic component: Hairy-lipped man (B.4. LBE); red-rimmed eyes (B.4. LBE); dark, wild, queer heart (B.4. LBE).

The phraseological units with a gender component are less numerous: woman witch; a witch-woman; as a woman (B.1. WE - B.4. LBE); woman who could change herself into a dragon; man of power; man witch (B.1. WE - B.4. LBE); wizardry was man's work; man's skills.

The number of phraseological units to denote animal features indicate a significant role of animals in highlighting the specifics of the hyperreal world: with wings like birds (B.4. LBE); borne by webbed wings (B.4. LBE); men and women were winged; the first musculature of the wings

Phraseological units-simulacra to denote the place: doorway of the sky (B.4. LBE); the dark land; the dry land; the dry river (B.3. FS); the end of earth; the farthest west (B.3. FS); as far away as Selidor; the dark places (B.3. FS; B.4 LBE); at the center of the world; where sea meets the sky; out of the north and west; farther west than west; whereas units with the temporal component are few: as long ago as forever; the end of an age; the beginning of time; that outlived old age.

To the third group belongs substantial number of expressions with magic component: great mage; art of magic; wizard's staff; mage-born (B.1. WE); mage's staff; beyond the power of wizards (B.1. WE); creatures like wizards (B.1. WE); woman witch; man witch; shape changing; bone setting; spell of finding; love potion; fertility charms; potency spells (B.1. WE); spell of changing; spell of transformation; spell of binding; spell of beguilement; women witch; charms of illusions; gift of healing; gift of chanting; gift of spellcasting; to witch oneself; to set smb's spell; to work illusions; to lay a curse (B.1. WE).

To the subcategory with anthropomorphic concept we refer simulacra of the phraseological level with the anthropomorphic component of dragon: dragon-blood; dragonpeople (B.4. LBE); the speech of dragon; dragon seed; woman who could change herself into a dragon; the Dragon Year; a dragon who could change itself into a woman; it's not easy talking to dragons; dragonlord; dragons do not have plain minds; dragons are thinking creatures (B.1. WE).

The prevailing number of simulacra in the third group to denote magic rituals, skills, artefacts proves the global role of MAGIC in the hyperreal world. It is posited that MAGIC is HYPERREALITY.

According to the prepositions filling the slots presented in the frames of the text under investigation - The Thing Frame, the Action Frame, the Possession Frame, the Identification Frame, the Comparison Frame (Zhabotinskaja, 1999: 12-25), it is possible to make such a classification of phraseological units-simulacra of reality.

Taking into account the filling of the slots of the Thing frame, the phraseological units in the text of the Earthsea cycle due to denotative characteristics fall into the following classification: 


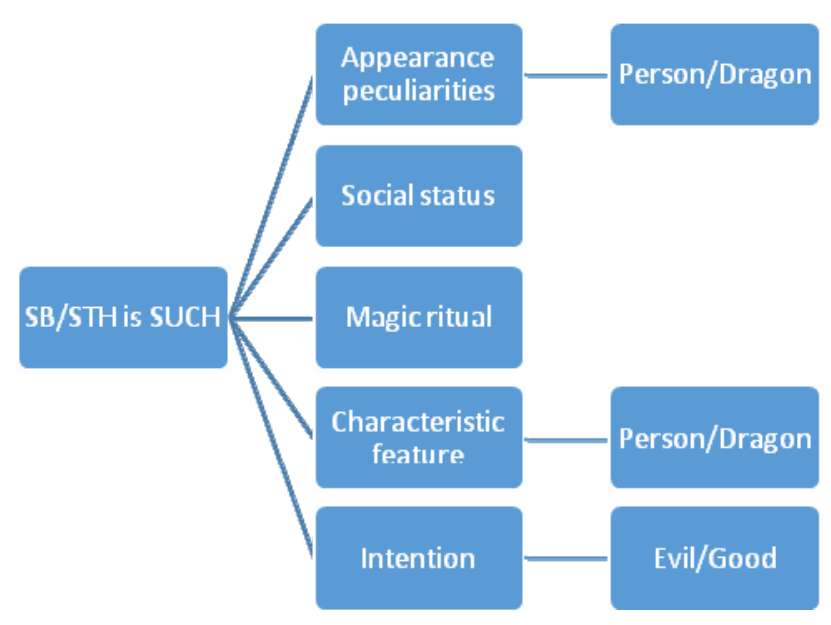

Figure 1. Explication of the slot SB/STH is SUCH at phraseological level

Phraseological units-simulacra, filling this slot, can be classified according to a denotative feature onto the units to denote the appearance peculiarities (both of a person or a dragon), characteristic features, social status, intentions (evil or good), and magical ritual.

So, the group of phraseological units to designate the features of the appearance is comprised of two subgroups - denoting the appearance of a person and a dragon. Expressions, which denote the appearance of a person, are as follows: narrow-eyed man; hairy-lipped me; smooth-skinned, mild-looking man; red-rimmed eyes; lipless mouth; man's form and body (B.1. WE).

As opposed to that, the phraseological units which formed a subgroup to denote the features of the appearance of the dragon are more numerous: sinuous iron-dark body; outreaching claws; narrow nose and flaring fuming nostrils; wings scarlet where sun shone on them; the first musculature of the wings; thorny tail; rustled wings; taloned foot; crooked elbow; rust-dark mail of dragon's neck; long yellow eye of a dragon; dragons of pale, red, blue and green; a red dragon

The advantage of the phraseological units to designate the appearance of the dragon testifies the importance of the dragon for the hyperreal world under investigation; the details of his appearance indicate the intention of the author to portray her own image, which to some extent contradicts stereotypical images about this mythological creature.

Phraseological units-simulacra, which explicate the motivational basis of the characteristic feature, form subgroups to denote the characteristic features of both a person and a dragon.

Hence, such phraseological units as bawling-voiced; tending a little too fat; little bag of skin; the third eye; dark, wild, queer heart; the heat of his body; little bag with eyes and voice; flying ends of her hair; men and women were winged; shining fire all about her head; a man dragons will talk to (B.4. LBE); god-figures maxed of dolphin, fish, man and sea-bird (B.3. FS); a dour creature; dragon-people (B.4. LBE); shadow-beast; woman's magic; the Dragon Year; the power of a woman, burned one-eyed child; a shrewd and modest man (B.4. LBE) designate a person, while dragon-blood; fire-serpent; dragons born of land and wind; speech of dragons; dragon seed; dragonlord; beast of wind and fire; snake-scaled reveal the characteristic features of a dragon.

By "characteristic feature" in this respect, we understand the distinguishing feature that gives colouring to a character or mythological creature. 
Phraseological units-simulacra denoting social status within the cycle are as follows: man of power; man witch; great mage (B.1. FS); she-archmage (B.4. LBE); woman witch; ordinary witch; village witch (B.1. WE). Such examples state the interrelation between the social status of the characters in the Earthsea Archipelago and the magic proper.

Some units can decode the intentions of the characters of the novels of the Earthsea cycle, showing both evil and good: wicked witch; great mage; witch-tinker; witches were fierce, bitter women (B.4. LBE). Such units certify that witch-woman is a bearer of evil intentions, while a man is a bearer of the good ones.

Within the novels of the cycle the slot for the Thing frame SB/SMTH is SUCH is filled with the following phraseological units to denote magic rituals: the art of magic; shape change; bone setting; spell of finding; love potion; fertility charms; potency spells; spell of chanting; spell of transformation; spell of binding; spell of beguilement; charms of illusions; gift of healing; gift of chanting; gift of spellcasting; charms and spells; finding and mending; wizard's staff (B.1. WE - B.4. LBE). Such a significant number of expressions to denote magical rituals testifies that magic occupies the central place in characters' lives in particular, in the Earthsea Archipelago in general.

Within the texts under investigation we may also single out the following slot of the Thing frame SB/STH is (exists) THERE (SOMEWHERE), which gets its explication (Fig. 2) in such phraseological units

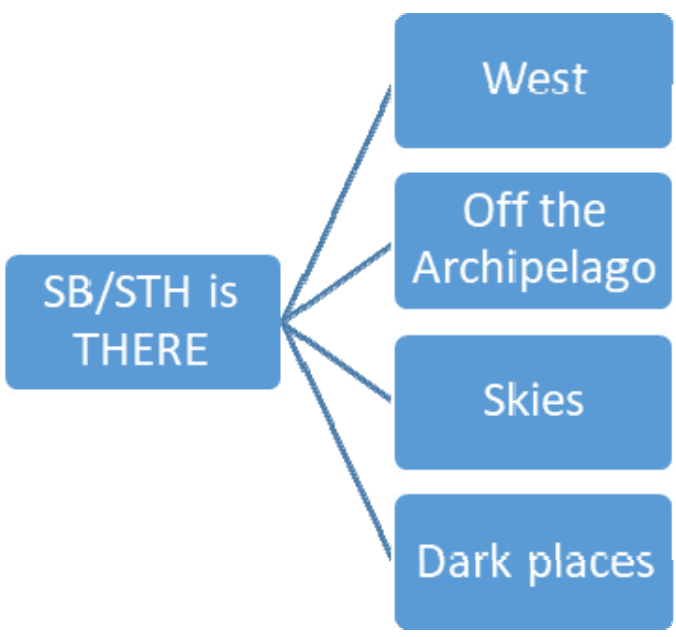

Figure 2. Explication of the slot SB/STH at THERE at phraseological level

Locations in the text are primarily related to the geographical indicator - the western direction, which is expressed by such simulacra as: the farthest west; out of the north and west; farther west than west (B.3. FS); outside the Archipelago - the end of earth; as far away Selidor; at the center of the world; is Selidor, but not Selidor; off the map (B.3. FS).

However, there is a number of figurative units providing information and the location not related to geographical objects on the map, like:

a) the sky - doorway of the sky; where the sea meets the sky and with the places of domination and the residence of evil-dark land; dry land; dry river;

b) the dark places - where sea runs dry; where joy runs out; the black hole; between light and darkness; beyond the power of wizards (B.3. FS).

The slot of the Thing frame SB/SMTH is (exists) SO is being explicated by the units to denote the type of activity and characteristic features (Fig. 3). 
Thus, we allocate the following phraseological units-simulacra to indicate the kind of activity: healer or finder; a second mate; dragon-people gathered up treasures; dragon people built houses; cast charms and worked spells [B.4. LBE]; weatherworker; patterner (B.1. WE), while expressions, denoting a characteristic feature are as follows: heart going hard; some hawk in him [B.1. WE] breath caught in the throat; bourn by webbed wings; men must not look into dragon's eyes; where wings had a root; the hawk was in him (B.1. WE), wizardry was a man's work; skills; in a complete animal gesture; dragons and human were all one; witch knows witch; spells going wrong; wings half lifted; with a large metallic sound (B.4. LBE).

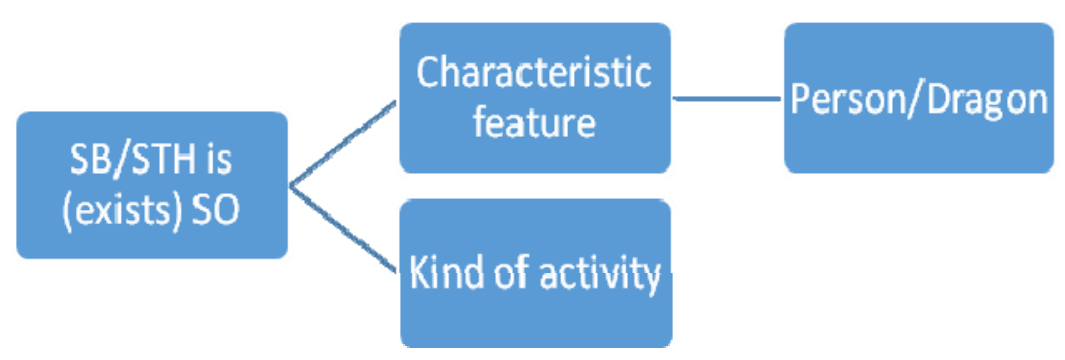

Figure 3. Explication of the slot SB/STH at SO at phraseological level

Taking into account the phraseological units to indicate the characteristic feature, we classify them into two groups, which denote personal traits - heart going hard; some hawk in him (B.1. WE) breath caught in the throat; spells going wrong; the hawk was in him (B.1. WE); wizardry was a man's work; skills; witch knows witch; and some particular features of dragon - men must not look into dragon's eyes, nor dragon; bourn by webbed wings; where wings had a root; in a complete animal gesture; dragons and human were all one; wings half lifted; with a large metallic sound (B.4. LBE).

Hence, the explication of the following slot of the Thing frame SB/STH is SO provides information about the kinds of activity of the characters, about their work, as well as their characteristic features, which make both individuals and dragons distinctive.

Phraseological units-simulacra also explicate the following slots of the Action frame SB/STH acts BY MEANS OF, SB/STH acts FOR (THE SAKE OF), SB/STH acts UPON (somebody, something). Such units of the phraseological level contribute to adequate understanding of the existing information about the activity of the characters in the Earthsea cycle, as well as give it an expressive emotional colouring.

Hence, phraseological units, filling the slot SB/STH acts BY MEANS OF, are to be classified as follows (Fig. 4):

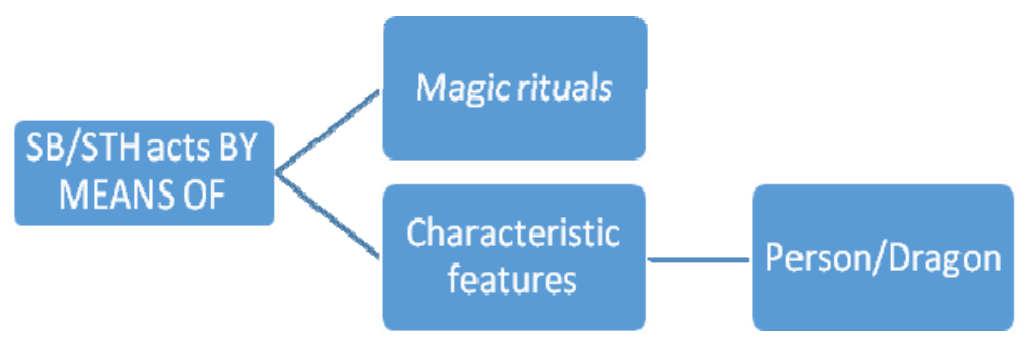

Figure 4. Explication of the slot SB/STH acts BY MEANS OF at phraseological level 
According to our classification, the slot is explicated by the phraseological unitssimulacra to denote magic rituals and characteristic features (of a person and a dragon). Hence, we find the following expressions to denote magic rituals, which are quite usual for magic hierarchy representatives - to work illusions; to lay a curse; to perform lowly jobs of finding and mending, to cast a spell (B.4. LBE) and others.

Characteristic features explicated in the following units denote personal characteristics - lips and tongue would not form a word (B.4. LBE); magic was made by men; could not put off the falcon; mage may know it without your telling him (B.1. WE), and some of the dragon - lowered his body into a crouch (B.4. LBE).

The slot SB/STH acts FOR (THE SAKE OF) something of the Action frame is filled with units-simulacra, which, according to intentions, can be classified (Fig. 5) onto the units to denote help, transformation, and personal interest.

Therefore, in the text we find such units to denote the process of transformation: woman could not change herself into a dragon; mage became a bear; became a pilgrim hawk; turn into another-take form (B.1. WE).

To confirm that magic is used by the inhabitants of the Earthsea Archipelago for their personal interests we find out such phraseological units, as to use power for body's lust. Magic in the Earthsea is thought to be a means of assistance and helping, hence the following phraseological units prove it: cast a spell to find a child; cast a spell of finding and mending; to cast a spell of increase (B.4. LBE) and others.

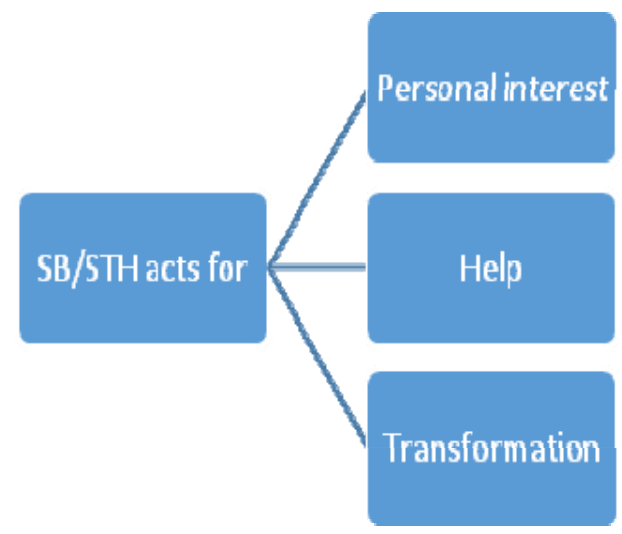

Figure 5. Explication of the slot SB/STH acts FOR (THE SAKE OF) at phraseological level

The units-simulacra, which filled this slot, testified that magic skills and knowledge were used for good purposes only.

Discovering the object of any magical activity, described in the novels of the Earthsea cycle, it seems rather obvious to analyse the simulacra of the phraseological level, which explicate the slot SB/STH acts UPON someone (something) (Fig. 6). The analysis carried out showed two vectors in the activity direction - regarding another person and regarding the self. Certifying this approach, such units are to be found:

- acting upon another person - forget what a man thinks; how do you speak to a man of power? (B.4. LBE); he stayed a bird (B.1. WE) to set somebody's spell; slay a wicked witch (B.4. LBE); change him into a monster;

- acting upon oneself - turn itself into a gull; the wizard may turn itself into a gull; to witch oneself (B.4. LBE). 


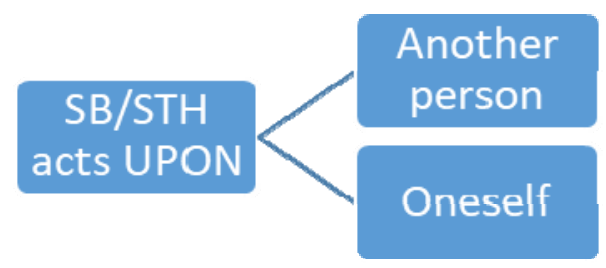

Figure 6. Explication of the slot SB/STH acts UPON at phraseological level

The obtained results testified the tendency of the characters, acting rather upon another person than the self.

The phraseological units-simulacra that filled the slot of the Comparison frame, according to the object of comparison, are to be classified as follows (Fig. 7). The comparison within the phraseological units is being carried out in five directions - with an animal, a bird, a representative of the magic hierarchy, a kind of activity and concepts, that is, both with objects of living and inanimate nature.

A characteristic feature of the study is the fact that more often a dragon is compared to the animal and the bird, while a person is compared with the type of activity, the representative of the magical hierarchy and concepts.

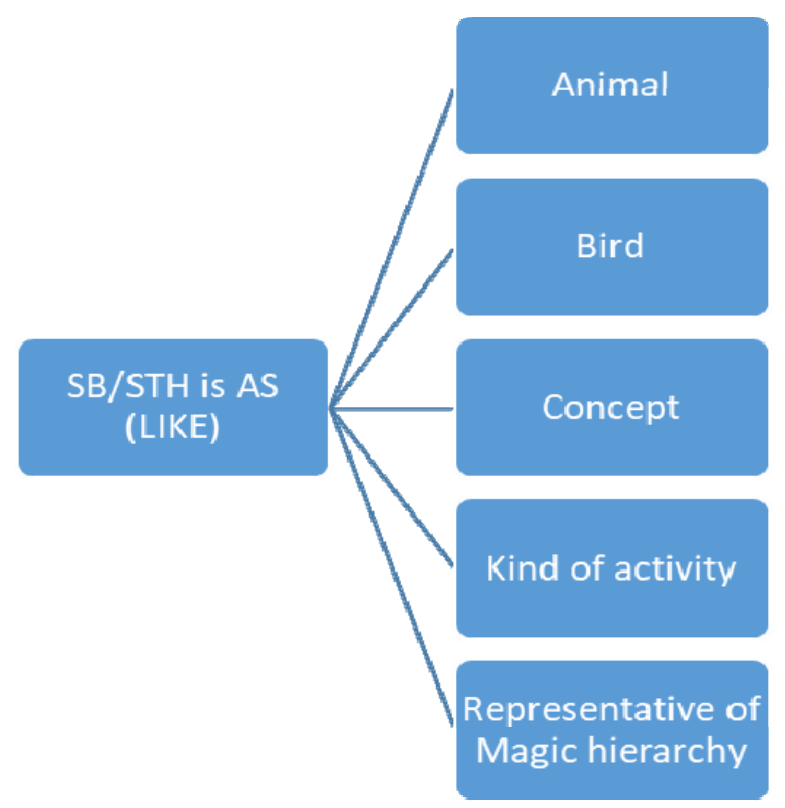

Figure 7. Explication of the slot SB/STH is AS (LIKE) at phraseological level

Phraseological units representing a comparison of an object with the animal are as follows: body arched like greyhound's; clawed like a lizard; creatures like lizards; trapped them as animals (B.4. LBE); whereas simulacra to demonstrate the metaphorical transfer of features of a bird are: with wings like birds; flying like a bird (B.1. WE).

Phraseological units, which objectivize comparison with a representative of the magic hierarchy, are as follows: as a woman witch; staff like wizard's (B.1. WE; B.4 LBE) and others. Thus, the motivational feature does not concern a person only, as a representative of a certain magic hierarchical stage, but also the artefacts inherent to them. 
Phraseological units denoting a concept, explicating within the slot of the Comparison frame, mainly focus on the concept of MAGIC - weak as woman magic; wicked as woman magic (B.4. LBE).

Simulacra providing a metaphorical transference from a kind of activity are not numerous, nevertheless they demonstrate the specific features of a person, such as: woman's tongue is worse than any thief (B.4. LBE).

Thus, the transference of the features of the fauna representatives and the signs of the material world provide an emotional colouring to simulacra of reality.

\section{Discussion.}

The prevailing number of phraseological units-simulacra explicating the slots of the Thing Frame has shown the importance of attributive characteristics of Earthsea objects for unambiguous and unified interpretations of the author's intentions.

The units-simulacra of the phraseological level as expressive-emotional units of the sacred nature supplemented and expanded the information on the multi-faceted hyperreal world, which is in the focus of our interest.

A detailed and thorough analysis of phraseological units-simulacra enables to create a representation model of reality in the novels of Ursula Le Guin of the Earthsea cycle, which will promote adequate understanding and comprehension of the hyperreal fantasy world in general (see illustrations).

\section{Conclusions.}

To summarize the abovementioned, we state that fictional worlds, fantasy fictional worlds in particular, are unique and specific individual mental constructs. Usually fantasy authors provide readership with their own world with distinct laws and simulated reality, thought to be "real". This effect of "unreal reality", known as hyperreality (according to postmodern philosophy), needs a detailed and thorough comprehension and interpretation, which becomes possible by means of frame modelling only. In this respect, frame semantics is the key to discovering the mechanisms for conceptualizing verbalized notions and phenomena of hyperreality.

The Earthsea cycle by Le Guin, composed of six books, proposes such a detailed fictional world, a hyperreal one, realized at lexical and phraseological levels.

A scrupulous survey of the phraseological potential of the texts under investigation allows to interpret fictional world of Le Guin in general, and make some conclusions about it in particular.

The plane of content of the figurative units of the simulated reality is revealed within three frames - The Thing, The Action and The Comparison Frames. Explication of the slots of the Thing and Comparison Frames gave some attributive characteristics of a person and a dragon, while the Action Frame disclosed information about activities of the characters.

The proposed frame model of hyperreal world at phraseological level enables to attribute to decoding the fictional world of the Earthsea Archipelago.

\section{References} kul'tury.

Arutjunova, N. D. (1998). Jazyk i mir cheloveka [Human language and world]. M. : Jazyki russkoj

Asmus, N. G. (2005). Lingvisticheskie osobennosti virtual'nogo kommunikativnogo prostranstva [Linguistic features of the virtual communication]: Thesis' Abstract. Cheljabinsk.

Attebery, B. (1980). The Fantasy Tradition in American Literature: From Irving to Le Guin. Bloomington: Indiana University Press.

Baudrillard, J. (1994). Simulacra and Simulation. MI. University of Michigan Press. 
Babushkin, A. P. (2001). "Vozmozhnye miry" v semanticheskom prostranstve jazyka ["Possible worlds" in the semantic space of a language]. Voronezh. VGU.

Baksanskij, O. E. (2001). Reprezentirovanie real'nosti: kognitivnyj pohod [Representation of reality: a cognitive approach]. M. : Al'teks.

Barbanjuk, O. O. (2012) Metonimichni motyvacijni modeli predmetnogho frejmu ghiperrealjnosti $\mathrm{v}$ khudozhnikh tvorakh Ursuly Le Ghujin cyklu "Eathsea" [Methonomic motivation models of the Thing frame of hyperreality in fiction of Ursula Le Guin Earhsea cycle]. Naukovi praci Kam'janecj-Podiljsjkogho nacionaljnogho universytetu imeni Ivana Oghijenka. Filologhichni nauky, 31. 11-14.

Bernardo, S. M., Murphy, G. J. (2006). Ursula K. Le Guin: A Critical Companion. $1^{\text {st }}$ ed. Westport, CT : Greenwood Press.

Boldyrev, N. N. (2001). Kognitivnaja semantika: (Kurs lekcij po angl. filologii) [Cognitive semantics: lecture course on English philology]. Tambov : Izd-vo TGU.

Boldyrev, N. N. (2004). Konceptual'noe prostranstvo kognitivnoj lingvistiki [Conceptual space of cognitive linguistics]. Voprosy kognitivnoj lingvistiki, 1. 18-36.

Croft, W, Cruse, D. (2004). Cognitive Linguistics. Cambridge: Cambridge University Press.

Eco, U. (1983). Travels in Hyperreality. San Diego and New York: Harcourt Brace and Company.

Fillmore, Ch. (1985) Frames and the semantics of understanding. Quaderni di Semantica, 6. 222-254.

Il'inova, E. Ju. (2007) Konceptologija vymysla v tekste avtorskoj skazki [Conceptology of fiction in the text of the author's fairy-tale]. Filologicheskie nauki, 1. 85-93.

Ivanov, V. V. (1982). Semantika vozmozhnyh mirov i filologija [Semantics of possible worlds and philology]. Problemy strukturoj lingvistiki 1980. 304.

Kovtun, E. N. (1999). Pojetika neobychajnogo: hudozhestvennye miry fantastiki, volshebnoj skazki, pritchi i mifa (na materiale evropejskoj literatury pervoj poloviny XX veka) [Poetics of extraordinary: fiction worlds of science fiction, fairy tales, parables and myths (on the material of European literature of the first half of the XXth century)]. M. : Izd-vo MGU.

Korotkova, L. V. (2001) Semantiko-kognitivnyj i funkcional'nyj aspekty tekstovyh anomalij $v$ sovremennoj anglojazychnoj hudozhestvennoj proze [Semanic, cognitive and functional aspects of textual anomalies in modern English prose]: Thesis' Abstract. Kiev.

Kozak, S. V. (2007) Relevantnistj teoriji frejmiv u suchasnij linghvistyci [Relevance of the theory of frames in modern linguistics]. Naukovyj visnyk Volynsjkogho derzh. u-tu im. L. Ukrajinky. VIII. Koghnityvna linghvistyka, 3. 257-260.

Koljadenko, O. O. (2013). Term "frame" in linguistics. Terminolohichnyi visnyk. Retrieved from http://www.irbis-nbuv.gov.ua/cgi-bin/irbis_nbuv/cgiirbis_64.exe?I21DBN=LINK\&P21DBN=UJRN\&Z21ID= 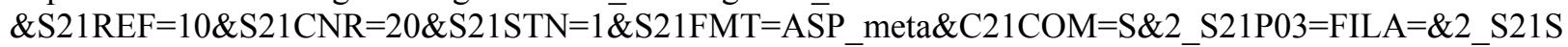 TR=termv_2013_2\%281\%29

Kubrjakova, Ye. S. (1992). Problemy predstavlenija znanij v sovremennoj nauke i rol' lingvistiki v reshenii jetih problem [Knowledge representation issues in modern science and the role of linguistics to overcome them]. Jazyk i struktura predstavlenija znanij. 4-38.

Kubrjakova, Ye. S (2004). Jazyk i znanie. [Language and knowledge]. M. : Jazyki slavjanskoj kul'tury.

Lakoff, G. (1980). Metaphors We Live By. Chicago; London: Chicago Univ. Press.

Levickij, A. Je. (1998). Funkcional'nye podhody k klassifikacii edinic sovremennogo anglijskogo jazyka [Functional approaches to the classification of modern English units]. K. : ASA.

Lomakova, A. V. (2005). Kul'turnyj mif v hudozhestvennom tvorchestve U. K. Le Guin [Cultural myth in the fiction of Ursula Le Guin]: Thesis' Abstract. M.

Lugovaja, E. A. (2010). Virtual'noe prostranstvo proizvedenij zhanra "fantasy" kak gipertekst: (Na materiale jepopei Dzh. R. R. Tolkiena "Vlastelin kolec") [Virtual space of fantasy genre as hypertext (based on Tolkien's epic "The Lord of the Rings")]. Gipertekst kak ob'ekt lingvisticheskogo issledovanija. 83-86.

Lugovaja, E. A. (2007). Gendernaja specifika virtual'nogo prostranstva proizvedenij "Vlastelin kolec" Dzh. R. R. Tolkiena i "Volshebnik Zemnomor'ja" U. Le Guin [Gender specificity of virtual space in Tolkien's "The Lord of the Rings" and "A Wizard of Earthsea" by U. Le Guin]. Mezhdisciplinarnye lingvisticheskie issledovanija. 61-64.

Mamchur, E. A. (2000). Koncepcija vozmozhnyh mirov i mir nauchnogo znanija [Concept of possible worlds and the world of scientific knowledge]. Koncepcija virtual'nyh mirov i nauchnoe poznanie. 229-233. 
Manlove, C. N. (1986). Science Fiction: Ten Explorations. Kent: Kent State University.

Minsky, M. A. (1975). Framework for Representing Knowledge. The Psychology of Computer Vision. ed. P. H. Winston. 211-277.

Misnik, M. F. (2005). Lingvisticheskaja realizacija vymyshlennogo mira $v$ zhanre fjentezi [Linguistic realization of the fictional fantasy world]. Voprosy teorii teksta, lingvostilistiki i intertekstual'nosti-Vestnik IGLU. Lingvistika. 93-107.

Nikonova, Zh. V. (2009). Frejmovyj analiz rechevyh aktov (na materiale nemeckogo jazyka) [Frame analysis of speech acts (based on the German language)]: Thesis' Abstract. Nizhnij Novgorod.

Novosadska, O. B. (2018). The concept of Frame and the Framing Process. Science and Education a New Dimension. Philology, VI (43). 150. 38-40. Retrieved from https://doi.org/10.31174/SEND-PH2018150VI43-09

Pavlova, I. V. (2014). Frejm kak osnovnaja model reprezentazii znanij [Frame as the main model of knowledge representation]. Sistema i struktura shidnoslov'jans'kih mov, 7. 118-123.

Petruck, M. (1996). Frame Semantics. Handbook of Pragmatics. eds J. Verschueren, J.-O. Ostman, J. Blommaert and C. Bulcaen. 1-13.

Philippopoulos-Mihalopoulos, A. (2005). Between Light and Darkness Earthsea and the Name of Utopia. Contemporary Justice Review, 8, 1. 45-57.

Plotnikova, S. N. (1997) Kognitivnye principy sozdanija anomal'nogo hudozhestvennogo mira [Cognitive principles to create an anomalous fiction world]. Problemy stilistiki i pragmatiki vyskazyvanija $i$ teksta: mezhvuz. sb. nauch. tr. 106-114.

Plotnikova, S. N. (2005). Konceptual'nyj standart zhanra fjentezi [Conceptual standard of fantasy genre]. Zhanry rechi: sb. nauch. st. Zhanr i koncept, 4. 262-272.

Rozinkina, T. A. (2005). Pragmaticheskij potencial leksicheskogo komponenta tekstov nemeckogo utopicheskogo romana [Pragmatic potential of the lexical component in German utopian novel]. Obshheteoreticheskie i tipologicheskie problemy jazykoznanija: trudy mezhdunarodnoj nauchno-prakticheskoj konferencii. 131-136.

Selivanova, O. O. (2008). Suchasna linghvistyka: naprjamy ta problemy [Modern linguistics: trends and challenges]. Poltava: Dovkillja-K.

Semino, E., Wynne, M. (1999). Hypothetical words and thoughts in contemporary British narratives. Narrative, 7. 307-334.

Tannen, D. (1979). What's in a frame? Surface evidence for underlying expectations. In New Directions in Discourse Processing. ed. R. Freedle. 137-181.

Telija, V. N. (1996). Russkaja frazeologija. Semanticheskij, pragmaticheskij, lingvokul'turologicheskij aspekty [Russian phraseology. Semantic, pragmatic, linguistic and cultural aspects]. M. : Shkola "Jazyki russkoj kul'tury".

Tyshchenko, O. (2018). Semantychna deryvacija remisnychoji terminologhiji u poljsjkij ta anghlijsjkij movakh (na materiali mizhmovnykh perekladnykh ekvivalentiv terminologhiji tkactva) [Semantic derivation of craft terminology in Polish and English languages (on the material of interlanguage translation equivalents of the terminology of weaving)]. Naukovyj Chasopys Nacionaljnogho pedaghoghichnogho universytetu imeni M. P. Draghomanova. Serija 9. Suchasni tendenciji rozvytku mov, 15. 203-212. Retrieved from https://sjnpu.com.ua/index.php/journal/article/view/95

Vardzelashvili, Zh. A. (2003). Vozmozhnye miry tekstual'nogo prostranstva [Possible textual worlds]. Sankt-Peterburgskij gosudarstvennyj universitet $i$ Tbilisskij gosudarstvennyj universitet. Nauchnye trudy. Serija: Filologija, VII. 37-45.

Vezhbickaja, A. (1996) Jazyk. Kul'tura. Poznanie [Language. Culture. Cognition]. M. : Russkie slovari.

Zhabotinskaja, S. A. (1999) Konceptual'nyj analiz: tipy frejmov [Conceptual analysis: types of frames]. Visnik Cherkas'kogo derzhavnogo universitetu im. B. Hmel'nic'kogo. Serija Filologichni nauki, 11. 12-25.

Zhabotinskaja, S. A. (2009) Modeli reprezentacii znanij v kontekste razlichnyh shkol kognitivnoj lingvistiki: integrativnyj podhod [Knowledge representation models in the context of different schools of cognitive linguistics: an integrative approach]. Visnik Harkivs'kogo nacional'nogo universitetu im. V. N. Karazina. Kognitivna lingvistika, 848. 3-10. 


\section{List of Il lustrative Material}

B. 1. Guin, Ursula le $A$ Wizard of Earthsea. Retrieved from http://readr.ru/ursula-le-guin-a-wizard-ofearthsea.html. atuan.html.

B. 2. Guin, Ursula le The Tombs of Atuan. Retrieved from http://readr.ru/ursula-le-guin-the-tombs-of-

B. 3. Guin, Ursula le The Farthest Shore. Retrieved from http://readr.ru/ursula-le-guin-the-farthestshore.html.

B. 4. Guin, Ursula le Tehanu. The Last Book of Earthsea. Retrived from http://readr.ru/ursula-le-guintehanu-the-last-book-of-earthsea.html.

B. 5. Guin, Ursula le The Other Wind. Retrieved from http://readr.ru/ursula-le-guin-the-otherwind.html.

B. 6. Guin, Ursula le Tales from Earthsea. Retrieved from http://readr.ru/ursula-le-guin-tales-fromearthsea.html

\section{Бібдіографічний опис:}

Барбанюк, О. О. (2018). Репрезентаційна модель гіперреального світу фентезі: фразеологічний вимір. Науковий часопис Національного педагогічного університету імені М. П. Арагоманова. Серія 9. Сучасні тенденцій розвитку мов, 18. 5-22. DOI: https://doi.org/10.31392/NPU-nc.series9.2018.18.01

\section{Анотація}

Стаття присвячена найбільш традиційній моделі представлення знань - фрейму, що є ключем до виявлення механізмів конщептуалізащії явищ навколищньої або текстової реальності. Можливі світи як текстова реальність $\epsilon$ ментальними конструктами, які потребують відповідної інтерпретації, зокрема вигадані світи жанру фентезі. Такі світи розуміються як гіперреальні, оскільки вони пропонують моделювання реальності, замінюючи реальне за допомогою знаків об'єктивної реальності - симулякрів. Гіперреальний світ в романах ичиклу Земномор'я, створений Урсулою Ле Гуїн, об'єктивується на лексичному і фразеологічному рівнях, відповідно, лексемамисимулякрами $i$ фразеологізмами-симулякрами. Такі одиничі фразеологічного потенціалу творів класифікуються за їх семантикою, позначаючи людину, місие, час і окреме поняття. Переважна кількість магічної складової засвідчила основоположну роль иього явища для досліджуваного гіперреального світу. Встановлено, що фразеологічні одиниці-симулякри, щцо заповнюють слоти Предметного, Акиіонального і Компаративного фреймів, дозволяють розшифрувати інформаиію про гіперреальний світ у цілому, збагачуючи його атрибутивними характеристиками персонажів та позначеннями різних видів їхньої діяльності. Запропонована модель репрезентації гіперреального вигаданого світу підтвердила здобуті результати та дозволила розкрити план змісту авторського конструкту. Так, фразеологізми-симулякри отримують своє змістове наповнення у межах таких слотів 1) Предметного фрейму: ХТОСЬ/ЩОСЬ є ТАКИЙ, ХТОСЬ/ЩОСЬ є (існує) ТАК, ХТОСЬ/ЩОСЬ $\epsilon$ ТУТ(ТАМ), декодуючи інформачію про характерні риси та місие проживання персонажів; 2) Акиіонального фрейму: ХТОСЬ/ЩОСь діє НА, ХТОСЬ/ЩОСЬ діє ЗАДЛЯ, ХТОСЬ/ЩОСЬ діє $3 А$ ДОПОМОГОЮ, розкриваючи особливості ӥхньої діяльності; 3) Компаративного фрейму: ХТОСЬ/ЩОСЬ є НАЧЕ, НІБИ, збагачуючи досліджуваний гіперреальний світ експресивно-емотивними характеристиками.

Ключові слова: фрейм, слот, експлікайія, модель репрезентації, гіперреальність, симулякр, фразеологізми-симулякри, вигаданий світ, фентезі. 


\section{REPRESENTATION MODEL OF HYPERREALITY: \\ PHRASEOLOGICAL DIMENSION}

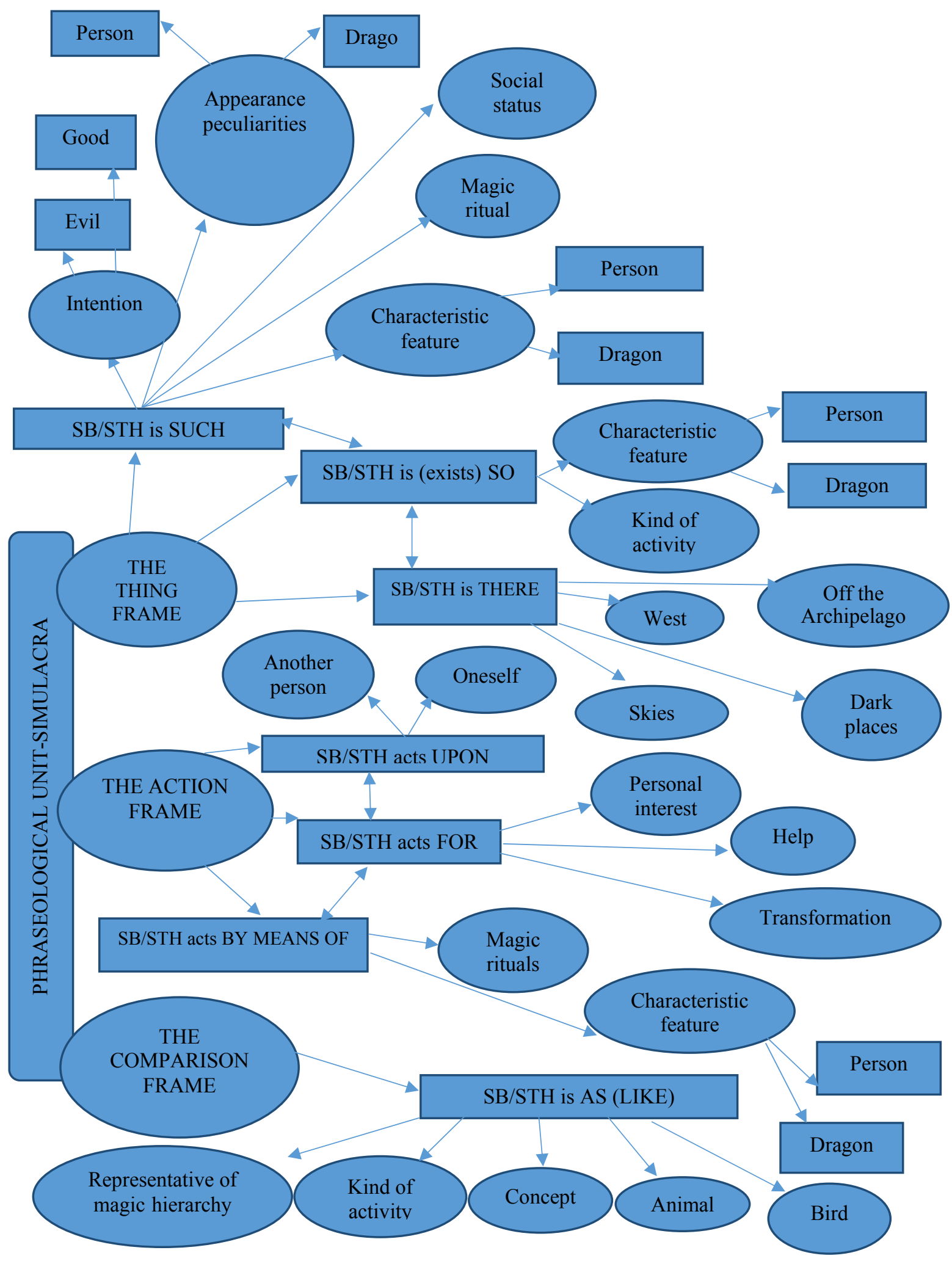

